О. М. Цігульова, О. М. Шуміло, О.О. Дєєва. - Київ: ФОП «Клименко», 2016. - 447 c.

3. Уряд затвердив Технічний регламент на косметичну продукцію. URL: https: //www.apteka.ua/article/580989. (Дата звернення: 20.02.2021).

4. US and EU Cosmetics Regulation. URL: https://cosmeticsinfo.org/ cosmetics-regulation (Date of access: 05.01.2021).

5. Regulation (EC) No 1223/2009. European parliament and of the council of 30 November 2009 on cosmetic products. Official Journal of the European Union. 2009. P. L 342 / 59 L 342/209.

6. Kazakova Iryna, Viacheslav Lebedynets. Analysis of the state of technical regulation of turnover of cosmetic productions in Ukraine. ScienceRise. 2020. № 2(67). P. 19-26.

7. Казакова I.C., Лебединець В.О. Аналіз та визначення перспектив розвитку ринку лікарських косметичних косметичних засобів в Україні. Соціальна фармачія в охороні здоров 'я. 2020. Т. 6. № 2. С. 44-60.

8. Казакова І.С., Лебединець В.О., Казакова В.С. Проблематика стандартизації лікарських косметичних засобів в Україні. Вісник фармації. 2020. № 2(100). C. 84-94.

DOI https://doi.org/10.30525/978-9934-26-038-4-54

\title{
DETERMINATION OF FRUCTANS CONTENT IN SOME PLANT ANTIDIABEIC MIXTURES
}

\author{
Savych A. O. \\ Candidate of Pharmacy (Ph.D.), \\ Assistant Professor at the Department \\ of Pharnacognosy with Medical Botany \\ Ivan Horbachevsky Ternopil National Medical University \\ of the Ministry of Health of Ukraine \\ Marchyshyn S. M. \\ Doctor of Pharmacy (Dr. Habil.), Professor, \\ Head of the Department of Pharnacognosy with Medical Botany \\ Ivan Horbachevsky Ternopil National Medical University \\ of the Ministry of Health of Ukraine \\ Ternopil, Ukraine
}

Diabetes mellitus is one of WHO's priority issues. It requires immediate resolution as the epidemiological situation is gaining alarming proportions - 
the number of diabetic patients is increasing every year along with the number of deaths and disabilities due to the development of angiopathies. According to the official information of International Diabetes Federation (2019), the number of patients is projected to increase to 642 million by 2040 [1].

Therefore, the optimization of pharmacotherapy, search and study of new drugs with hypoglycemic activity for the prevention and treatment of this disease and its dangerous complications is a top issue of modern pharmacy and medicine.

One of these areas is using the plant remedies, either as monotherapy for the prevention or in the mild stages of the disease or in the combination with traditional therapy in more severe forms of the disease. Phytotherapy is a justified method for the prevention and treatment because it has some advantages, such as relatively low toxicity, mild pharmacological effects and possibility to be used for long periods without significant side-effects, and it often well combines with synthetic drugs, has a complex activity through a number of biologically active compounds $[2,3,4]$. Particular attention deserve the combinations of different medicinal plants, because such plant mixtures will have more biologically active substances that will influence on the all links of the pathogenetic mechanism of development of diabetes mellitus and its complications $[5,6,7,8]$.

Thus, the aim of our research was to determine the quantitative content of fructans by spectrophotometric method in the plan antidiabetic mixtures.

The objects of study were the plant antidiabetic mixtures No. 3 (Urtica dioica leaf, Cichorium intybus roots, Rosa majalis fruits, Elymus repens rhizome, Taraxacum officinale roots) No. 4 (Arctium lappa roots, Elymus repens rhizome, Zea mays columns with stigmas, Helichrysum arenarium flowers, Rosa majalis fruits), No. 7 (Inula helenium rhizome with roots, Helichrysum arenarium flowers, Zea mays columns with stigmas, Origanum vulgari herb, Rosa majalis fruits, Taraxacum officinale roots), No. 13 (Cichorium intybus roots, Elymus repens rhizome, Helichrysum arenarium flowers, Rosa majalis fruits, Zea mays columns with stigmas), No. 19 (Urtica dioica leaf, Taraxacum officinale roots, Vaccinium myrtillus leaf, Rosa majalis fruits, Mentha piperita herb), which have proven hypoglycemic, hypolipidmic, antioxidant properties [9, 10, 11, 12, 13, 14]. It was used the herbal raw materials harvested in June - August 2019 in Ternopil region and Charpathians (Vaccinium myrtillus leaf) (Ukraine) during the study.

The quantitative content of the fructans was determined by spectrophotometric method using spectrophotometer Shimadzu (Japon). $3.00 \mathrm{~g}$ of each sample of crushed plant mixture was extracted by $100 \mathrm{~mL}$ of water at the water bath under reflux at $80^{\circ} \mathrm{C}$ for 1 hour. To prepare an initial solution the extracts were cooled, filtered and the volumes were completed to $100 \mathrm{~mL}$ by 
water. To prepare a tested solution $2 \mathrm{~mL}$ of an initial solution was placed into $100 \mathrm{~mL}$ volumetric flask and $50 \mathrm{~mL}$ of $5 \%$ hydrochloric acid was added. The obtained solution was hydrolysed at the water bath under reflux for 2 hours. Than $2.0 \mathrm{~mL}$ of cooled hydrolysate was placed into $50 \mathrm{~mL}$ volumetric flask and added $5 \%$ hydrochloric acid to the mark. To prepare a comparison solution $2 \mathrm{~mL}$ of the initial solution was placed into $50 \mathrm{~mL}$ volumetric flask and added $5 \%$ hydrochloric acid to the mark. The absorbance of the tested solutions were measured at a wavelength of $285 \mathrm{~nm}$ relative to the compensatory solution. The total content of fructans in the studied plant mixtures was calculated as 5-Hydroxymethyl-2-furaldehyde and it represents the average of five determinations. Statistical processing and data analysis were performed using Statistica v 10.0 program package for Microsoft Office.

The results of spectrophotometric determination showed that the plant mixture No. 3 contains $6.39 \pm 0.01 \%$ fructans, the plant mixture No. $4-2.79 \pm 0.01 \%$, the plant mixture No. $7-2.96 \pm 0.01 \%$, the plant mixture No. $13-3.79 \pm 0.01 \%$ and the plant mixture No. $19-4.93 \pm 0.01 \%$. Fructans are very important biologically active substances for the treatment and prevention of diabetes because they have hypoglycemic, hypolipidemic and detoxifying properties.

\section{References:}

1. International Diabetes Federation / IDF Diabetes Atlas. 9th ed. Brussels, 2019.

2. Савич А. О., Марчишин С. М., Козяр Г. Р, Скринчук О. Я. Основні принципи використання лікарських рослин та їх зборів для лікування та профілактики цукрового діабету 2 типу (Огляд літератури). Фітотерапія часопис. 2019. № 4. С. 43-46.

3. Савич А. О., Марчишин С. М., Кравчук Л. О. Дослідження якісного складу та кількісного вмісту флавоноїдів у зборах антидіабетичних № 3 і № 4 методом ВЕРХ. Актуальні питання фармацевтичної $і$ медичної науки та практики. 2020. Т. 13, № 2 (33). C. 219-224.

4. Савич А. О., Марчишин С. М. Аналіз мінерального складу рослинних антидіабетичних зборів. Медична та клінічна хімія. 2020. T. 22. № 2. C. 81-86.

5. Савич А. О., Марчишин С. М., Лемішка Т. І. Вивчення амінокислотного складу збору лікарських рослин 3 антидіабетичною активністю. Медична та клінічна хімія. 2020. Т. 22. № 4. С. 96-102.

6. Savych A., Marchyshyn S., Milian I. Determination of carbohydrates in the herbal antidiabetic mixtures by GC-MC. Acta Pharmaceutica. 2021. Vol. 71 (3). P. 429-443. 
7. Savych A., Marchyshyn S., Basaraba R. Determination of fatty acid composition content in the herbal antidiabetic collections. Pharmacia. 2020. № 67 (3). P. 153-159.

8. Savych A., Marchyshyn S., Kozyr H., Yarema N. Determination of inulin in the herbal mixtures by GC-MS method. Pharmacia. 2021. № 68(1). P. 181-187.

9. Savych A., Marchyshyn S., Doroshenko O. Screening of hypoglycemic activity of herbal mixtures (Message 2). Ukrainian biopharmaceutical journal. 2020. № 3 (64). - P. 22-29.

10. Savych A. O., Marchyshyn S. M., Milian I. I. Screening study of hypoglycemic activity of herbal mixtures (Presentation 3). Clinical Pharmacy. 2020. Vol. 24, № 4. P. 38-46.

11. Savych A. O., Marchyshyn S. M., Basaraba R. Yu. Determination of hypoglycemic activity of the herbal mixtures in screening study. Pharmacology and Drug Toxicology. 2020. № 14 (5). P. 344-351.

12. Savych A., Marchyshyn M., Basaraba R., Lukanyuk M. Antihyperglycemic, hypolipidemic and antioxidant properties of the herbal mixtures in dexamethasone-induced insulin resistant rats. PharmacologyOnLine. 2020. № 2. P. 73-82.

13. Savych A., Marchyshyn M., Basaraba R., Screening study of hypoglycemic activity of the herbal mixtures (Message 1). Scientific Journal «ScienceRise: Pharmaceutical Science». 2020. № 4(26). P. 40-46.

14. Savych A. O., Marchyshyn S. M., Basaraba R. Yu. Influence of the herbal mixtures on the functional state of the liver in dexamethasoneinduced insulin resistant rats. New trends and unresolved issues of preventive and clinical medicine: international scientific and practical conference materials, Lublin, 23-24 September 2020. Lublin, Republic of Poland. P. 113-116. 